\title{
Identifying treatment response to antihypertensives in patients with obesity-related hypertension
}

Ilse M. Schrover ${ }^{1}$, Jannick A. N. Dorresteijn ${ }^{1}$, Jodine E. Smits', A. H. Jan Danser², Frank L. J. Visseren ${ }^{1}$ and Wilko Spiering ${ }^{1 *}$

\begin{abstract}
Background: In patients with obesity-related hypertension $(\mathrm{ORH})$, reaction to antihypertensive medication is likely influenced by patientcharacteristics.

Methods: Effects of aliskiren, moxonidine and hydrochlorothiazide on 24-h blood pressure (BP) were compared to placebo. Linear mixed effect models were used to analyze the effect of patient characteristics on BP levels and treatment response.

Results: Systolic BP response to aliskiren was higher in patients with a BMI $>30.7 \mathrm{~kg} / \mathrm{m} 2$ compared to patients with a $B M I \leq 30.7 \mathrm{~kg} / \mathrm{m} 2(-21 \mathrm{mmHg}$ versus $-4 \mathrm{mmHg})$. In patients with a hsCRP $>1.8 \mathrm{mg} / \mathrm{L}$ the systolic BP response to aliskiren was higher than in patients with a low hsCRP $(-15 \mathrm{mmHg}$ versus $-7 \mathrm{mmHg})$. Hydrochlorothiazide (HCTZ) treatment effect on systolic BP was $-13 \mathrm{mmHg}$ when heart rate $>71$ beats $/ \mathrm{min}$ compared to $-3 \mathrm{mmHg}$ when heart rate was $\leq 71$ beats/min.
\end{abstract}

Conclusion: In patients with ORH, BP response to aliskiren is positively related to BMl and hsCRP. Systolic BP response to HCTZ is positively related to heart rate and negatively to renin levels.

Trial registration: NCT01138423. Registered June 4th, 2010.

Keywords: Hypertension, Obesity, Treatment, Interaction

\section{Background}

Subjects who are either overweight or obese have a 2 time higher risk of developing hypertension as compared to persons with a normal BMI $[1,2]$. In patients with this so-called obesity-related hypertension (ORH), both blood pressure level as well as the reaction to antihypertensive medication are likely to be influenced by patient characteristics. Age and gender are known to influence blood pressure levels in the general population and are likely to also influence blood pressure in patients with ORH. At age $55,7 \%$ of the Western population is diagnosed with hypertension [1], which rises to $34 \%$ at age 65 and $77 \%$ at age 80 [3]. Women (72\%) are more

\footnotetext{
* Correspondence: w.spiering@umcutrecht.nl

${ }^{1}$ Department of Vascular Medicine, University Medical Center Utrecht,

P.O. Box 85500, 3584, GA, Utrecht, The Netherlands

Full list of author information is available at the end of the article
}

likely to develop hypertension than men (61\%) during their lifetime [3].

Patient characteristics linked to the underlying pathophysiological mechanisms of ORH could also influence blood pressure. The major underlying mechanism linking obesity to hypertension is thought to be adipose tissue dysfunction, defined as an imbalance between the release of pro- and anti-inflammatory adipokines, resulting in activation of the renin-angiotensin-aldosterone system (RAAS), sympathetic overdrive, low-grade inflammation and oxidative stress [4-7]. Eventually, this leads to endothelial dysfunction, vascular hypertrophy and impaired natriuresis $[4,8]$. In a previous study, we showed that in subjects with ORH the blood pressure lowering effect was greatest during treatment with direct renin inhibitor aliskiren [9].

Knowledge of patient characteristics that influence the blood pressure response to antihypertensive treatment in 
patients with ORH may help to identify the most effective blood pressure lowering treatment in individual patients. Response to anti-hypertensive medication varies significantly in patients with previously untreated primary hypertension [10-12] and is therefore presumably dependent on patient-specific characteristics such as gender, age, BMI, salt intake and level of RAAS hormones [12-18].

In the present study we evaluated which patient characteristics influence the blood pressure-lowering effect of the direct renin inhibitor aliskiren, the sympathicolytic agent moxonidine and the diuretic hydrochlorothiazide in patients with ORH.

\section{Methods}

We used data from a cross-over trial in which 31 previously untreated patients with ORH were successively treated with aliskiren, moxonidine, hydrochlorothiazide (HCTZ) and matching placebo, in random order, each for 8 weeks. A detailed description of the methods has been published earlier [9]. In summary, a four-way, double-blind, single-center, crossover study was performed in 31 adult Caucasian patients (men and post menopausal women) with previously untreated ORH from September 2010 until March 2012. ORH was defined as a blood pressure $>130 \mathrm{mmHg}$ systolic and/or $>85 \mathrm{mmHg}$ diastolic and abdominal obesity (waist circumference $>102 \mathrm{~cm}$ (men) or $>88 \mathrm{~cm}$ (women)). This is in accordance with the metabolic syndrome criteria, which all patients fulfilled [19].

(Pre)hypertension was defined as office systolic blood pressure (SBP) $>130 \mathrm{mmHg}$ and/or office diastolic blood pressure $(\mathrm{DBP})>85 \mathrm{mmHg}$ during two screening visits on separate days. Blood pressure was measured two times on both arms in sitting position after the subject had been seated for some minutes using an appropriately sized arm-cuff and an automated oscillometric blood pressure device [20]. Blood pressure level was defined as the highest mean of the measurements on one arm during the first visit, and as the mean of the measurements on that same arm during all subsequent visits. When subjects were eligible to participate in the study they entered a 40 -weeks study-period in which they received each of four subsequent once daily monotherapies sequentially: aliskiren $300 \mathrm{mg}$, moxonidine $0.4 \mathrm{mg}$, HCTZ $25 \mathrm{mg}$, and matching placebo. The efficacy of each treatment on ambulatory (24-h) blood pressure was assessed after 8 weeks. The study was conducted in accordance with the principles of the Declaration of Helsinki as adopted by the 59th WMA general assembly, Seoul 2008. The institutional review committee of the University Medical Center Utrecht approved the study and all patients gave their written informed consent.

\section{Data analyses}

A linear mixed effect model was used to determine which characteristics modified the relationship between treatment (aliskiren, moxonidine or HCTZ) and 24-h systolic and diastolic blood pressure (DBP), adjusted for time since randomization, age and gender. Patient characteristics considered were gender, BMI, waist, age, fasting glucose, mean 24-h heart rate, aldosterone, renin, muscle sympathetic nerve activity (MSNA), 24-h urine sodium excretion, hsCRP, adiponectin and leptin. These characteristics were measured during placebo treatment (in fasting condition between 7 and 9 am), except BMI and waist circumference, which were only measured at study baseline. MSNA was only performed in a subgroup of 15 patients due to the invasiveness and timeconsuming nature of the measurement. Adiponectin, leptin and hsCRP levels were logtransformed due to their skewed distribution. All available follow-up data were included in the analyses even when patients did not complete all four treatments. The 95\% confidence intervals $(95 \% \mathrm{CI})$ were approximated on the basis of the coefficients' standard errors.

In the analysis determining characteristics influencing reaction to medication, scale variables were dichotomized at the median level and treatment effect was presented accordingly, combined with $p$-values for interaction. Analyses were performed with the statistical package R, version 2.11.1 (R Foundation for Statistical Computing, www.R-project.org).

\section{Results}

Baseline characteristics

Patients consisted of 23 men and 8 women with a median age of 60 years (IQR 55-63 years), a median BMI of $30.7 \mathrm{~kg} / \mathrm{m}^{2}$ (IQR $27.7-32.2 \mathrm{~kg} / \mathrm{m}^{2}$ ) and a median office blood pressure of 153/88 mmHg (IQR 145-167 mmHg systolic and 84-96 mmHg diastolic; Table 1).

\section{Determinants of blood pressure response to aliskiren}

Table 2 shows the relation between patient characteristics and 24-h SBP in response to treatment with the RAAS-inhibitor aliskiren.

SBP response to aliskiren was significantly related to BMI. SBP decreased with $21 \mathrm{mmHg}$ (95\% CI -27 to $-14 \mathrm{mmHg}$ ) in patients with a BMI above the median of $30.7 \mathrm{~kg} / \mathrm{m}^{2}$ versus a decrease of $4 \mathrm{mmHg}(95 \% \mathrm{CI}-9$ to $1 \mathrm{mmHg}$ ) in those with a BMI below the median, ( $p$ for interaction $=0.01$ ).

SBP response was also significantly related to hsCRP in patients with $>1.8 \mathrm{mg} / \mathrm{L}(-15 \mathrm{mmHg}, 95 \% \mathrm{CI}-20$ to $-10 \mathrm{mmHg}$ ) compared with patients with $\leq 1.8 \mathrm{mg} / \mathrm{L}$ $(-7 \mathrm{mmHg}, 95 \% \mathrm{CI}-12$ to $-2 \mathrm{mmHg}$, $\mathrm{p}$ for interaction $=0.03)$. None of the other patient characteristics 
Table 1 Patient characteristics during treatment with placebo

\begin{tabular}{|c|c|c|}
\hline Characteristic & & $N=31$ \\
\hline \multirow[t]{2}{*}{ Sex } & Men $(n, \%)$ & $23(74 \%)$ \\
\hline & Women (n, \%) & $8(26 \%)$ \\
\hline Age (years) & & $60(55-63)$ \\
\hline BMI $\left(\mathrm{kg} / \mathrm{m}^{2}\right)^{\mathrm{a}}$ & & $30.7(27.7-32.2)$ \\
\hline \multirow[t]{2}{*}{ Waist circumference $(\mathrm{cm})^{a}$} & Men & $111(107-116)$ \\
\hline & Women & $98(95-99)$ \\
\hline \multirow[t]{2}{*}{ Office blood pressure $(\mathrm{mmHg})$} & Systolic & $153(145-167)$ \\
\hline & Diastolic & $88(84-96)$ \\
\hline \multirow[t]{2}{*}{ 24-h blood pressure $(\mathrm{mmHg})$} & Systolic & $131(124-144)$ \\
\hline & Diastolic & $80(76-87)$ \\
\hline Heart rate (beats/min) & & $71(69-79)$ \\
\hline MSNA (bursts/min) & & $46(39-50)$ \\
\hline Sodium intake (mmol/day) & & $87(58-118)$ \\
\hline Fasting glucose (mmol/L) & & $5.6(5.0-6.0)$ \\
\hline Total cholesterol (mmol/L) & & $5.7(5.1-6.2)$ \\
\hline \multirow[t]{2}{*}{ HDL-cholesterol (mmol/L) } & Men & $1.02(0.94-1.22)$ \\
\hline & Women & $1.31(1.28-1.76)$ \\
\hline Triglycerides (mmol/L) & & $1.90(1.40-2.30)$ \\
\hline hsCRP (mg/L) & & $1.8(1.3-3.3)$ \\
\hline eGFR $\left(\mathrm{ml} / \mathrm{min} / 1.73 \mathrm{~m}^{2}\right)$ & & $79(73-86)$ \\
\hline Renin $(p g / m l)$ & & $57.2(42.4-79.4)$ \\
\hline Aldosterone (pg/ml) & & $53.4(33.2-76.4)$ \\
\hline Adiponectin $(\mu \mathrm{g} / \mathrm{ml})$ & & $68.9(51.9-104.1)$ \\
\hline Leptin (ng/ml) & & $16.4(9.5-33.2)$ \\
\hline
\end{tabular}

Data are presented as medians and interquartile ranges unless otherwise indicated

$B M I$ body mass index, HDL-cholesterol high density lipoprotein cholesterol, eGFR Glomerular Filtration Rate, as estimated by the Modification of Diet in Renal Disease (MDRD) equation, MSNA muscle sympathetic nerve activity, hsCRP high sensitivity $C$ reactive protein

${ }^{\mathrm{a}} \mathrm{BMI}$ and waist circumference were only measured at baseline

was an effect modifier in the relation between treatment with aliskiren and blood pressure reduction.

\section{Determinants of blood pressure response to hydrochlorothiazide}

Table 3 shows the relation between patients characteristics on 24-h SBP response to diuretic therapy with hydrochlorothiazide. During treatment with HCTZ, blood pressure response was significantly related to resting heart rate. When heart rate was $>71$ beats/min there was a decrease of $13 \mathrm{mmHg}(95 \% \mathrm{CI}-19$ to $-7 \mathrm{mmHg}$ ) in SBP as opposed to a decrease of $3 \mathrm{mmHg}(95 \% \mathrm{CI}-7$ to $2 \mathrm{mmHg}$ ) in SBP when heart rate was $\leq 71$ beats $/ \mathrm{min}$ ( $p$ for interaction $=0.03$ ). Renin level was also an effect modifier in the relation between treatment with HCTZ and blood pressure reduction. Renin levels below the
Table 2 Effect of RAAS inhibition (aliskiren 300 mg) on 24-h SBP

\begin{tabular}{|c|c|c|c|}
\hline & & 24-h SBP & P for interaction \\
\hline \multirow[t]{2}{*}{ Sex } & Men & $-13(-18$ to -8$)$ & 0.75 \\
\hline & Women & $-4(-7$ to -2$)$ & \\
\hline \multirow[t]{2}{*}{ Age } & $>60$ years & $-7(-12$ to -2$)$ & 0.88 \\
\hline & $\leq 60$ years & $-11(-15$ to -6$)$ & \\
\hline \multirow[t]{2}{*}{ BMI } & $>30.7$ kg/m2 & $-21(-27$ to -14$)$ & 0.01 \\
\hline & $\leq 30.7 \mathrm{~kg} / \mathrm{m} 2$ & $-4(-9$ to 1$)$ & \\
\hline \multirow[t]{2}{*}{$\begin{array}{l}\text { Waist } \\
\text { (sexpooled) }\end{array}$} & $\begin{array}{l}\text { Men }>111 \mathrm{~cm} \\
\text { Women }>98 \mathrm{~cm}\end{array}$ & $-17(-25$ to -9$)$ & 0.39 \\
\hline & $\begin{array}{l}\text { Men } \leq 111 \mathrm{~cm} \\
\text { Women } \leq 98 \mathrm{~cm}\end{array}$ & $-10(-14$ to -5$)$ & \\
\hline \multirow[t]{2}{*}{ Heart rate $^{\mathrm{b}}$} & $>71 / \mathrm{min}$ & $-14(-20$ to -7$)$ & 0.71 \\
\hline & $\leq 71 / \mathrm{min}$ & $-9(-14$ to -4$)$ & \\
\hline \multirow[t]{2}{*}{ MSNA } & $>46$ bpm & $-9(-17$ to 1$)$ & 0.16 \\
\hline & $\leq 46 \mathrm{bpm}$ & $-9(-15$ to -3$)$ & \\
\hline \multirow[t]{2}{*}{ hsCRPc } & $>1.8 \mathrm{mg} / \mathrm{L}$ & $-15(-20$ to -10$)$ & 0.03 \\
\hline & $\leq 1.8 \mathrm{mg} / \mathrm{L}$ & $-7(-12$ to -2$)$ & \\
\hline \multirow[t]{2}{*}{ Renin } & $>57.2 \mathrm{pg} / \mathrm{ml}$ & $-16(-22$ to -9$)$ & 0.73 \\
\hline & $\leq 57.2 \mathrm{pg} / \mathrm{ml}$ & $-9(-14$ to -3$)$ & \\
\hline \multirow[t]{2}{*}{ Aldosterone } & $>53.4 \mathrm{pg} / \mathrm{ml}$ & $-14(-21$ to -7$)$ & 0.75 \\
\hline & $\leq 53.4 \mathrm{pg} / \mathrm{ml}$ & $-11(-16$ to -6$)$ & \\
\hline \multirow[t]{2}{*}{ Sodium intake ${ }^{a}$} & > $87 \mathrm{mmol} / \mathrm{day}$ & $-14(-20$ to -7$)$ & 0.48 \\
\hline & $\leq 87 \mathrm{mmol} /$ day & $-9(-14$ to -4$)$ & \\
\hline \multirow[t]{2}{*}{ Glucose } & $>5.1 \mathrm{mmol} / \mathrm{L}$ & $-20(-26$ to -13$)$ & 0.13 \\
\hline & $\leq 5.1 \mathrm{mmol} / \mathrm{L}$ & $-8(-13$ to -3$)$ & \\
\hline \multirow[t]{2}{*}{ Adiponectin ${ }^{c}$} & $>68.9 \mu \mathrm{g} / \mathrm{ml}$ & $-11(-16$ to -6$)$ & 0.56 \\
\hline & $\leq 68.9 \mu \mathrm{g} / \mathrm{ml}$ & $-13.3(-20$ to -7$)$ & \\
\hline \multirow[t]{2}{*}{ Leptin $^{c}$} & $>16.4 \mathrm{ng} / \mathrm{ml}$ & $-16(-21$ to -10$)$ & 0.81 \\
\hline & $\leq 16.4 \mathrm{ng} / \mathrm{ml}$ & $-8(-13$ to -2$)$ & \\
\hline
\end{tabular}

BP change (95\% confidence interval) in $\mathrm{mmHg}$ from placebo in subgroups of patients corrected for age and gender. Patient characteristics were dichotomized on the median level and p's for interaction were determined accordingly $S B P$ systolic blood pressure, $B M I$ body mass index, MSNA muscle sympathetic nerve activity, $h s C R P$ high sensitivity C-reactive protein, $b p m$ beats per minute, $A B P M$ ambulatory blood pressure measurement

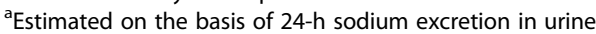

${ }^{\mathrm{b}}$ Measured with ABPM

'Log transformed

median of $57.2 \mathrm{pg} / \mathrm{ml}$ were related to larger SBP reductions $(-8 \mathrm{mmHg}, 95 \%-13$ to $-3 \mathrm{mmHg})$ than renin levels above the median $(-6 \mathrm{mmHg}, 95 \% \mathrm{CI}-12$ to $1 \mathrm{mmHg}$; for interaction $=0.04)$. None of the other patient characteristics was an effect modifier in the relation between treatment with HCTZ and blood pressure reduction.

Determinants of blood pressure response to moxonidine Table 4 shows the relation between participant characteristics and change in 24-h SBP in response to sympatholytic therapy with moxonidine. 
Table 3 Effect of diuretic therapy (HCTZ 25 mg) on 24-h SBP

\begin{tabular}{|c|c|c|c|}
\hline & & 24-h SBP & $\mathrm{P}$ for interaction \\
\hline \multirow[t]{2}{*}{$\overline{\text { Sex }}$} & Men & $-7(-12$ to -2$)$ & 0.35 \\
\hline & Women & $-4(-7$ to -2$)$ & \\
\hline \multirow[t]{2}{*}{ Age } & $>60$ years & $-4(-8$ to 1$)$ & 0.74 \\
\hline & $\leq 60$ years & $-7(-12$ to -3$)$ & \\
\hline \multirow[t]{2}{*}{ BMI } & $>30.7$ kg/m2 & $-11(-18$ to -5$)$ & 0.99 \\
\hline & $\leq 30.7 \mathrm{~kg} / \mathrm{m} 2$ & $-4(-9$ to 1$)$ & \\
\hline \multirow[t]{2}{*}{ Waist (sexpooled) } & $\begin{array}{l}\text { Men > } 111 \mathrm{~cm} \\
\text { Women }>98 \mathrm{~cm}\end{array}$ & $-8(-16$ to 1$)$ & 0.79 \\
\hline & $\begin{array}{l}\text { Men } \leq 111 \mathrm{~cm} \\
\text { Women } \leq 98 \mathrm{~cm}\end{array}$ & $-6(-11$ to -1$)$ & \\
\hline \multirow[t]{2}{*}{ Heart rate $^{b}$} & $>71 / \mathrm{min}$ & $-13(-19$ to -7$)$ & 0.03 \\
\hline & $\leq 71 / \mathrm{min}$ & $-3(-7$ to 2$)$ & \\
\hline \multirow[t]{2}{*}{ MSNA } & $>46$ bpm & $-6(-14$ to 3$)$ & 0.17 \\
\hline & $\leq 46 \mathrm{bpm}$ & $-8(-14$ to -1$)$ & \\
\hline \multirow[t]{2}{*}{ hs-CRPc } & $>1.8 \mathrm{mg} / \mathrm{L}$ & $-8(-14$ to -3$)$ & 0.70 \\
\hline & $\leq 1.8 \mathrm{mg} / \mathrm{L}$ & $-5(-10$ to 0$)$ & \\
\hline \multirow[t]{2}{*}{ Renin } & $>57.2 \mathrm{pg} / \mathrm{ml}$ & $-6(-12$ to 1$)$ & 0.04 \\
\hline & $\leq 57.2 \mathrm{pg} / \mathrm{ml}$ & $-8(-13$ to -3$)$ & \\
\hline \multirow[t]{2}{*}{ Aldosterone } & $>53.4 \mathrm{pg} / \mathrm{ml}$ & $-8(-15$ to -1$)$ & 0.54 \\
\hline & $\leq 53.4 \mathrm{pg} / \mathrm{ml}$ & $-7(-12$ to -2$)$ & \\
\hline \multirow[t]{2}{*}{ Sodium intake ${ }^{a}$} & $>87 \mathrm{mmol} /$ day & -7 (-13 to 0$)$ & 0.42 \\
\hline & $\leq 87 \mathrm{mmol} /$ day & $-8(-12$ to -3$)$ & \\
\hline \multirow[t]{2}{*}{ Glucose } & $>5.1 \mathrm{mmol} / \mathrm{L}$ & $-8(-15$ to -2$)$ & 0.74 \\
\hline & $\leq 5.1 \mathrm{mmol} / \mathrm{L}$ & $-6(-11$ to -1$)$ & \\
\hline \multirow[t]{2}{*}{ Adiponectin ${ }^{c}$} & $>68.9 \mu \mathrm{g} / \mathrm{ml}$ & $-8(-13$ to -3$)$ & 0.94 \\
\hline & $\leq 68.9 \mu \mathrm{g} / \mathrm{ml}$ & $-6(-13$ to 1$)$ & \\
\hline \multirow[t]{2}{*}{ Leptin $^{c}$} & $>16.4 \mathrm{ng} / \mathrm{ml}$ & $-10(-16$ to -4$)$ & 0.29 \\
\hline & $\leq 16.4 \mathrm{ng} / \mathrm{ml}$ & $-4(-10$ to 1$)$ & \\
\hline
\end{tabular}

BP change (95\% confidence interval) in $\mathrm{mmHg}$ from placebo in subgroups of patients corrected for age and gender. Patient characteristics were dichotomized on the median level and p's for interaction were determined accordingly

$S B P$ systolic blood pressure, $B M I$ body mass index, MSNA muscle sympathetic nerve activity, $h s C R P$ high sensitivity $C$-reactive protein, bpm beats per minute, $A B P M$ ambulatory blood pressure measurement

${ }^{\mathrm{a} E s t i m a t e d}$ on the basis of $24-\mathrm{h}$ sodium excretion in urine

${ }^{\mathrm{b}}$ Measured with ABPM

'Log transformed

During moxonidine use, women $(-4 \mathrm{mmHg}$ SBP, 95\% CI -7 to $-1 \mathrm{mmHg}$ ) tended to have larger blood pressure reductions than men $(-3 \mathrm{mmHg}$ SBP, $95 \% \mathrm{CI}-8$ to $3 \mathrm{mmHg}$; for interaction $=0.06$ ).

Also, participants $\leq 60$ years $(-4 \mathrm{mmHg}, 95 \% \mathrm{CI}-9$ to $1 \mathrm{mmHg}$ ) compared with participants $>60$ years $(-2 \mathrm{mmHg}, 95 \% \mathrm{CI}-7$ to $3 \mathrm{mmHg}$; $\mathrm{p}$ for interaction $=0.09)$ tended to have larger reductions in SBP.

None of the other patient characteristics was an effect modifier in the relation between treatment with moxonidine and blood pressure reduction.
Table 4 Effect of sympatho-inhibition (moxonidine $0.4 \mathrm{mg}$ ) on 24-h SBP

\begin{tabular}{|c|c|c|c|}
\hline & & $24 \mathrm{~h} \mathrm{SBP}$ & $P$ for interaction \\
\hline \multirow[t]{2}{*}{$\overline{S e x}$} & Men & $-3(-8$ to 3$)$ & 0.06 \\
\hline & Women & $-4(-7$ to -1$)$ & \\
\hline \multirow[t]{2}{*}{ Age } & $>60$ years & $-2(-7$ to 3$)$ & 0.09 \\
\hline & $\leq 60$ years & $-4(-9$ to 1$)$ & \\
\hline \multirow[t]{2}{*}{$\mathrm{BMI}$} & $>30.7$ kg/m2 & -4 ( -11 to 3$)$ & 0.91 \\
\hline & $\leq 30.7 \mathrm{~kg} / \mathrm{m} 2$ & -3 (-8 to 2$)$ & \\
\hline \multirow[t]{2}{*}{ Waist (sexpooled) } & $\begin{array}{l}\text { Men }>111 \mathrm{~cm} \\
\text { Women }>98 \mathrm{~cm}\end{array}$ & $-2(-10$ to 7$)$ & 0.84 \\
\hline & $\begin{array}{l}\text { Men } \leq 111 \mathrm{~cm} \\
\text { Women } \leq 98 \mathrm{~cm}\end{array}$ & -4 (-9 to 1$)$ & \\
\hline \multirow[t]{2}{*}{ Heart rate } & $>71 / \mathrm{min}$ & $-8(-15$ to -2$)$ & 0.53 \\
\hline & $\leq 71 / \mathrm{min}$ & $-1(-5$ to 4$)$ & \\
\hline \multirow[t]{2}{*}{ MSNA } & $>46$ bpm & 0 (-9 to 9$)$ & 0.15 \\
\hline & $\leq 46 \mathrm{bpm}$ & $-7(-14$ to 0$)$ & \\
\hline \multirow[t]{2}{*}{ hs-CRPc } & $>1.8 \mathrm{mg} / \mathrm{L}$ & $-5(-10$ to 1$)$ & 0.46 \\
\hline & $\leq 1.8 \mathrm{mg} / \mathrm{L}$ & $-2(-7$ to 3$)$ & \\
\hline \multirow[t]{2}{*}{ Renin } & $>57.2 \mathrm{pg} / \mathrm{ml}$ & -2 ( -9 to 5$)$ & 0.07 \\
\hline & $\leq 57.2 \mathrm{pg} / \mathrm{ml}$ & $-5(-11$ to 0$)$ & \\
\hline \multirow[t]{2}{*}{ Aldosterone } & $>53.4 \mathrm{pg} / \mathrm{ml}$ & $-4(-12$ to 3$)$ & 0.84 \\
\hline & $\leq 53.4 \mathrm{pg} / \mathrm{ml}$ & $-4(-9$ to 1$)$ & \\
\hline \multirow[t]{2}{*}{ Sodium intake ${ }^{a}$} & $>87 \mathrm{mmol} /$ day & $-4(-11$ to 4$)$ & 0.25 \\
\hline & $\leq 87 \mathrm{mmol} /$ day & $-4(-9$ to 1$)$ & \\
\hline \multirow[t]{2}{*}{ Glucose } & $>5.1 \mathrm{mmol} / \mathrm{L}$ & $-5(-12$ to 2$)$ & 0.81 \\
\hline & $\leq 5.1 \mathrm{mmol} / \mathrm{L}$ & -3 (-8 to 2$)$ & \\
\hline \multirow[t]{2}{*}{ Adiponectin ${ }^{c}$} & $>68.9 \mu \mathrm{g} / \mathrm{ml}$ & $-5(-10$ to 1$)$ & 0.31 \\
\hline & $\leq 68.9 \mu \mathrm{g} / \mathrm{ml}$ & -4 (-11 to 3$)$ & \\
\hline \multirow[t]{2}{*}{ Leptin $^{c}$} & $>16.4 \mathrm{ng} / \mathrm{ml}$ & $-6(-11$ to 1$)$ & 0.45 \\
\hline & $\leq 16.4 \mathrm{ng} / \mathrm{ml}$ & $-2(-8$ to 4$)$ & \\
\hline
\end{tabular}

BP change (95\% confidence interval) in $\mathrm{mmHg}$ from placebo in subgroups of patients corrected for age and gender. Patient characteristics were dichotomized on the median level and p's for interaction were determined accordingly

$S B P$ systolic blood pressure, $B M I$ body mass index, MSNA muscle sympathetic nerve activity, $h s C R P$ high sensitivity $C$-reactive protein, bpm beats per minute $A B P M$ ambulatory blood pressure measurement

${ }^{\mathrm{a} E s t i m a t e d}$ on the basis of 24-h sodium excretion in urine

${ }^{\mathrm{b}}$ Measured with ABPM

'Log transformed

\section{Sensitivity analyses}

In patients with a screening blood pressure of $>140$ / $90 \mathrm{mmHg}$, results were not significantly different from those in the patients with a screening blood pressure $>130 / 85 \mathrm{mmHg}$.

\section{Discussion}

In patients with obesity-related hypertension the characteristics BMI and hsCRP influence the blood pressure lowering effect of the RAAS inhibitor aliskiren. Heart rate and renin levels influence the effect of the diuretic 
HCTZ and age and gender influence the effect of the sympatho-inhibitor moxonidine.

The positive association between adipose tissue and blood pressure is mainly driven by visceral adipose tissue in males and by adipose tissue deposited elsewhere in females [16]. As a reaction to accumulation of visceral adipose tissue there is enhanced sympathoactivation, driven partly by testosterone levels. Therefore, blocking sympathoactivation might be more beneficial in reducing blood pressure in men than in women. Although women have lower sympathoactivation than men at all ages, women show a greater increase in sympathetic activity with increasing age [21, 22], followed by a more marked increase in mean blood pressure, suggesting that sympathetic activity has a greater influence on blood pressure in women than in men [21]. MSNA and, to a lesser extent, heart rate are indicative for sympathetic activation. Unexpectedly, we did see the best reaction to moxonidine on SBP in the younger patients. Although a standard maintenance dose of moxonidine ( $0.4 \mathrm{mg}$ once daily) was given, this might not have blocked all sympathetic activity, especially in those patients with high baseline sympathetic activity. This might also explain why MSNA did not modify the relationship between moxonidine and 24-h SBP, in combination with the relatively small number of patients [15] undergoing MSNA. Unexpectedly, heart rate was found to influence SBP when patients were treated with HCTZ, which does not exhibit sympatho-inhibitory effects [23]. To our knowledge, this has not been reported previously.

One of the other mechanisms underlying ORH is an inappropriately normal or even elevated RAAS activity. An increasing BMI is correlated to an augmented activity of the RAAS system [24, 25] as reflected in higher levels of angiotensinogen, renin, angiotensin I and angiotensin converting enzyme (ACE) in obese persons as compared to lean persons [24-26]. Independent adipose tissue production of angiotensinogen [27] and factors stimulating the adrenal gland in producing aldosterone [28] are presumably responsible for this enhanced activity in obese individuals. The synthesis and secretion of angiotensinogen in adipose tissue does not only contribute to elevated local angiotensin II concentrations, causing oxidative stress and local inflammation, but also lead to higher systemic RAAS activity [7].

Renin and aldosterone levels drop significantly with weight loss, even when the BMI remains $>25 \mathrm{~kg} / \mathrm{m}^{2}$, suggesting that there is a linear association between BMI and RAAS-activation. Inhibiting RAAS could therefore be more effective in terms of blood pressure reduction in individuals with the highest BMI [13]. Aliskiren, being a direct renin-inhibitor, is known to reduce RAAS activity at both the systemic level [29] and also penetrates the adipose tissue at levels sufficient to reduce tissue RAAS activity [30]. Since enhanced inflammation is, at least partly, a reflection of locally enhanced RAAS activation [31], this may explain the higher blood pressure reductions in patients with the highest hsCRP plasma concentrations. Unexpectedly, blood pressure lowering response to aliskiren was not influenced by either renin or aldosterone plasma concentrations, nor was there an influence of renin and aldosterone plasma concentrations on blood pressure level, despite the known inhibitory effect of aliskiren on both systemic and adipose tissue RAAS activity $[29,30]$. There is limited evidence supporting a role for measuring RAAS hormones as guidance for anti-hypertensive therapy. Small retrospective studies show conflicting results concerning the modifying effects of plasma renin activity (PRA) on the blood pressure lowering effect of RAAS inhibitors $[32,33]$. A small prospective study shows PRA to correlate with blood pressure reduction in patients treated with angiotensin receptor blockers [34]. In our study we did not measure PRA but plasma renin concentration (PRC), but both parameters are highly correlated in untreated individuals [35].

In ORH, due to impaired pressure natriuresis, volume overload can be an underlying pathophysiological phenomenon [4]. Both higher age and low renin levels are associated with a high intravascular volume status. Thus, older patients and those with low renin levels have a larger blood pressure reduction in response to diuretic therapy [12, 14, 17].

In this study, patients with the lowest plasma renin concentrations, an indication for high volume status, responded most to $\mathrm{HCTZ}$ therapy with respect to systolic blood pressure lowering. This is in line with observations in overweight hypertensive patients [14]. Contrary to our expectations, no influence on blood pressure response of sodium intake in either of the treatment arms was seen. For patients treated with aliskiren, 1 earlier study has shown that those on a low salt diet (<5 g NaCl/day) experience the greatest antihypertensive effect [18] compared to patients on a normal to high salt diet (> $10 \mathrm{~g} \mathrm{NaCl} /$ day), with a blood pressure difference of $9.4 \mathrm{mmHg}$. The same beneficial effect of a low sodium diet has been reported for ACE inhibitors and angiotensin receptor blockers [15]. A less prominent effect of low sodium diet is seen when patients are treated with other classes of antihypertensive drugs (calciumblockers, betablockers and diuretics), approximately $4 \mathrm{mmHg}$ blood pressure difference between a low and high sodium diet [15]. In both studies, a large difference in sodium intake was created, either by using a crossover design with one period of low and one period of high sodium intake or by using a 'normal' sodium intake control group opposed to a group instructed to adhere to a low sodium diet. In our study, no such contrast was 
created and since patients were asked to adhere to a normal salt diet, a relatively low sodium intake $(5.1 \mathrm{~g} \mathrm{NaCl} /$ day) was observed, which might explain why we did not find sodium intake to influence blood pressure response. Moreover, those studies did not exclusively study patients with ORH, although the mean BMI in both studies was $>25 \mathrm{~kg} / \mathrm{m} 2$.

Strengths and limitations of our study need to be considered. The influence on blood pressure response of possible effect modifiers could be analyzed during treatment with three different classes of antihypertensive medication, aimed at different pathophysiological mechanisms. Blood pressure and heart rate were measured very accurately with 24-h ambulant blood pressure measurements. An important limitation of this study is the relatively small sample size, especially the amount of women participating in the trial. In this study, participants were regarded hypertensive with a relatively low blood pressure of $>130 \mathrm{mmHg}$ systolic or $>85 \mathrm{mmHg}$ diastolic. In this patient category, there is no proof of better outcome with lowering blood pressure. However, the aim of our study was not to investigate the change in outcome of lowering blood pressure, but to study the pathophysiological reactions in patients with obesity and hypertension to different antihypertensive drugs. Moreover, not treating patients with a higher blood pressure and concomitant risk (metabolic syndrome) is unethical, and would undermine the careful design with a placebo period in this study.

Since many determinants were measured, some of the significant results might be false-positive due to multiple testing. However, determinants were not chosen and analyzed in a random way, but were chosen on their pathophysiological link with hypertension.

\section{Conclusions}

The blood pressure-lowering response of antihypertensive medication is for aliskiren influenced by BMI and hsCRP, for HCTZ by heart rate and renin levels and for moxonidine by gender.

This emphasizes the multi-factorial mechanism of development of ORH, with activation of the RAAS system, sympathetic activation and volume overload being causative factors. Patient characteristics may guide choice of blood pressure-lowering medication in patients with ORH.

\section{Abbreviations}

BMI: Body mass index; HCTZ: Hydrochlorothiazide; hsCRP: High-sensitivity C-reactive protein; MSNA: Muscle sympathetic nerve activity; ORH: Obesity-related hypertension; RAAS: Renin-angiotensin-aldosterone system; SAT: Subcutaneous adipose tissue; SBP: Systolic blood pressure; VAT: Visceral adipose tissue

\section{Acknowledgements}

We would like to acknowledge Mrs. Klaassen and Mrs. Joosten, trial-managers, for their great help in performing the Target-trial.

\section{Funding}

The Target, of which the data were used, was funded by a grant from Novartis Pharmaceuticals.

Availability of data and materials

Data are available on reasonable request.

\section{Authors' contributions}

IS and JD (Dorresteijn) drafted the manuscript; IS, JD (Dorresteijn), FV and WS were involved in analyzing and interpreting the data, JD (Danser) analyzed the renin and aldosteron samples and advised on the impact of their results. All authors read and approved the final manuscript.

\section{Ethics approval and consent to participate}

All procedures performed in this study involving human participants were in accordance with the ethical standards of the institutional and/or national research committee and with the 1964 Helsinki declaration and its later amendments or comparable ethical standards. This was judged by the Ethics Committee of the Universal Medical Center Utrecht, the Netherlands (reference number: 10-215/G-E).

\section{Consent for publication}

Not applicable.

\section{Competing interests}

The authors declare that they have no competing interests.

\section{Publisher's Note}

Springer Nature remains neutral with regard to jurisdictional claims in published maps and institutional affiliations.

\section{Author details}

${ }^{1}$ Department of Vascular Medicine, University Medical Center Utrecht, P.O. Box 85500, 3584, GA, Utrecht, The Netherlands. ${ }^{2}$ Division of Pharmacology and Vascular Medicine, Department of Internal Medicine, Erasmus Medical Center, Rotterdam, The Netherlands.

Received: 20 July 2017 Accepted: 18 September 2017

Published online: 24 October 2017

\section{References}

1. Schmidt M, Johannesdottir SA, Lemeshow S, Lash TL, Ulrichsen SP, Bøtker $H E$, et al. Obesity in young men, and individual and combined risks of type 2 diabetes, cardiovascular morbidity and death before 55 years of age: a Danish 33-year follow-up study. BMJ Open. 2013;3(4):e002698.

2. Shihab HM, Meoni LA, Chu AY, Wang N-Y, Ford DE, Liang K-Y, et al. Body mass index and risk of incident hypertension over the life course: the Johns Hopkins Precursors Study. Circulation. 2012;126(25):2983-89.

3. Ostchega Y, Dillon CF, Hughes JP, Carroll M, Yoon S. Trends in hypertension prevalence, awareness, treatment, and control in older U.S. adults: Data from the National Health and Nutrition Examination Survey 1988 to 2004. J Am Geriatr Soc. 2007;55(7):1056-65.

4. Dorresteijn JAN, Visseren FLJ, Spiering W. Mechanisms linking obesity to hypertension. Obesity Reviews. 2012;13(1):17-26.

5. Grassi G, Seravalle G, Cattaneo BM, Bolla GB, Lanfranchi A, Colombo M, et al. Sympathetic activation in obese normotensive subjects. Hypertension. 1995; 25(4):560-3.

6. Hajer GR, Van Haeften TW, Visseren FLJ. Adipose tissue dysfunction in obesity, diabetes, and vascular diseases. Eur Heart J. 2008;29(24):2959-71.

7. Thatcher S, Yiannikouris F, Gupte M, Cassis L. The adipose renin-angiotensin system: Role in cardiovascular disease. Mol Cell Endocrinol. 2009;302(2):111-17.

8. Steinberg HO, Paradisi G, Hook G, Crowder K, Cronin J, Baron AD. Free fatty acid elevation impairs insulin-mediated vasodilation and nitric oxide production. Diabetes. 2000;49(7):1231-38.

9. Dorresteijn JAN, Schrover IM, Visseren FL, Scheffer PG, Oey PL, Danser AHJ, et al. Differential effects of renin-angiotensin-aldosterone system inhibition, sympathoinhibition and diuretic therapy on endothelial function and blood pressure in obesity-related hypertension: a double-blind, placebo-controlled cross-over trial. J Hypertens. 2013;31(2):393-403. 
10. Deary AJ, Schumann AL, Murfet H, Haydock SF, Foo RS-Y, Brown MJ. Double-blind, placebo-controlled crossover comparison of five classes of antihypertensive drugs. J Hypertens. 2002;20:771-77.

11. Dickerson JEC, Hingorani AD, Ashby MJ, Palmer CR, Brown MJ. Optimisation of antihypertensive treatment by crossover rotation of four major classes. Lancet. 1999:353(9169):2008-13.

12. Materson BJ, Reda DJ, Cushman WC, Massie BM, Freis ED, Kochar MS, et al Single-Drug Therapy for Hypertension in Men - A Comparison of Six Antihypertensive Agents with Placebo. N Engl J Med. 1993;328:914-21

13. Ho JT, Keogh JB, Bornstein SR, Ehrhart-Bornstein M, Lewis JG, Clifton PM, et al. Moderate weight loss reduces renin and aldosterone but does not influence basal or stimulated pituitary-adrenal axis function. In: Hormone and Metabolic Research. 2007;39(9):694-99.

14. Huang CC, Chung CM, Hung SI, Leu HB, Wu TC, Huang PH, et al. Genetic variation in renin predicts the effects of thiazide diuretics. Eur J Clin Invest. 2011;41(8):828-35.

15. Huggins CE, Margerison C, Worsley A, Nowson CA. Influence of dietary modifications on the blood pressure response to antihypertensive medication. Br J Nutr. 2011;105(02):248-55.

16. Pausova Z, Mahboubi A, Abrahamowicz M, Leonard GT, Perron M, Richer L, et al. Sex differences in the contributions of visceral and total body fat to blood pressure in adolescence. Hypertension. 2012;59(3):572-9.

17. Preston RA, Materson BJ, Reda DJ, Williams DW, Hamburger RJ, Cushman WC, et al. Age-race subgroup compared with renin profile as predictors of blood pressure response to antihypertensive therapy. Department of Veterans Affairs Cooperative Study Group on Antihypertensive Agents. Jama. 1998;280(13):1168-72.

18. Weir MR, Yadao AM, Purkayastha D, Charney AN. Effects of high- and lowsodium diets on ambulatory blood pressure in patients with hypertension receiving aliskiren. J Cardiovasc Pharmacol Ther. 2010;15(4):356-63.

19. Grundy SM, Cleeman II, Daniels SR, Donato KA, Eckel RH, Franklin BA, et al. Diagnosis and management of the metabolic syndrome: An American Heart Association/National Heart, Lung, and Blood Institute scientific statement. Circulation. 2005;112(17):2735-52.

20. Pickering TG, Hall JE, Appel LJ, Falkner BE, Graves J, Hill MN, et al. Recommendations for blood pressure measurement in humans and experimental animals. Part 1: Blood pressure measurement in humans. Hypertension. 2005;45(1):142-61.

21. Narkiewicz K, Phillips BG, Kato M, Hering D, Bieniaszewski L, Somers VK. Gender-selective interaction between aging, blood pressure, and sympathetic nerve activity. Hypertension. 2005;45(4):522-25.

22. Ng AV, Callister R, Johnson DG, Seals DR, Johson DG, Seals DR. Age and Gender Influence Muscle Sympathetic Nerve Activity at Rest in Healthy Humans. Hypertension. 1993;21(4):498-503.

23. Grassi G, Seravalle G, Dell'Oro R, Trevano FQ, Bombelli M, Scopelliti F, et al. Comparative effects of candesartan and hydrochlorothiazide on blood pressure, insulin sensitivity, and sympathetic drive in obese hypertensive individuals: results of the CROSS study. J Hypertens. 2003; 21(9):1761-9.

24. Rossi GP, Belfiore A, Bernini G, Fabris B, Caridi G, Ferri C, et al. Body mass index predicts plasma aldosterone concentrations in overweight-obese primary hypertensive patients. J Clin Endocrinol Metab. 2008;93(7):2566-71.

25. Schorr U, Blaschke K, Turan S, Distler A, Sharma AM. Relationship between angiotensinogen, leptin and blood pressure levels in young normotensive men. J Hypertens. 1998;16(10):1475-80.

26. Engeli S, Böhnke J, Gorzelniak K, Janke J, Schling P, Bader M, et al. Weight loss and the renin-angiotensin-aldosterone system. Hypertension. 2005; 45(3):356-62.

27. Karlsson C, Lindell K, Ottosson M, Sjöström L, Carlsson B, Carlsson LMS Human adipose tissue expresses angiotensinogen and enzymes required for its conversion to angiotensin II. J Clin Endocrinol Metab. 1998;83(11):3925-29.

28. Lamounier-Zepter V, Ehrhart-Bornstein M, Bornstein SR. Mineralocorticoidstimulating activity of adipose tissue. Best Pract Res Clin Endocrinol Metab. 2005;19(4):567-75.

29. Angeli F, Reboldi G, Mazzotta G, Poltronieri C, Garofoli M, Ramundo E, et al. Safety and efficacy of aliskiren in the treatment of hypertension and associated clinical conditions. Curr Drug Saf. 2012;7(1):76-85.

30. Boschmann M, Nussberger J, Engeli S, Danser A HJ, Yeh C-M, Prescott MF, et al. Aliskiren penetrates adipose and skeletal muscle tissue and reduces renin-angiotensin system activity in obese hypertensive patients. J Hypertens. 2012;30(3):561-66.
31. Renna NF, Lembo C, Diez E, Miatello RM. Role of renin-angiotensin system and oxidative stress on vascular inflammation in insulin resistence model. Int J Hypertens. 2013;2013:420979.

32. Nussberger J, Gradman AH, Schmieder RE, Lins RL, Chiang Y, Prescott MF. Plasma renin and the antihypertensive effect of the orally active renin inhibitor aliskiren in clinical hypertension. Int J Clin Pract. 2007;61(9):1461-68.

33. Stanton AV, Dicker $P, O^{\prime} B r i e n ~ E T$. Aliskiren monotherapy results in the greatest and the least blood pressure lowering in patients with high- and low-baseline PRA levels, respectively. Am J Hypertens. 2009;22(9):954-57.

34. Minami J, Ishimitsu T, Matsuoka H. Pretreatment plasma renin activity levels correlate with the blood pressure response to telmisartan in essential hypertension. Am J Hypertens. 2008;21(1):10-13.

35. Danser J. Renin and prorenin as biomarkers in hypertension. Curr Opin Nephrol Hypertens. 2012;21(5):508-514.

\section{Submit your next manuscript to BioMed Central and we will help you at every step:}

- We accept pre-submission inquiries

- Our selector tool helps you to find the most relevant journal

- We provide round the clock customer support

- Convenient online submission

- Thorough peer review

- Inclusion in PubMed and all major indexing services

- Maximum visibility for your research

Submit your manuscript at www.biomedcentral.com/submit
) Biomed Central 